\title{
Improvement of Kriya Batik Learning Results Through the STAD Type Cooperative Learning Model
}

\author{
Dessy Wulandari ${ }^{1 *}$, Bukman Lian², Mulyadi ${ }^{2}$ \\ ${ }^{1}$ SMK Negeri 2 Kayuagung \\ ${ }^{2}$ Universitas PGRI Palembang, Indonesia \\ ${ }^{*}$ Corresponding author. Email: dessywulandari.spd@gmail.com
}

\begin{abstract}
The purpose of this research is to identify and classify the management increased yield learning the craft of batik through cooperative learning model STAD learners XI class textile craft SMK Negeri 2 Kayuagung. This study employs Classroom Action Research (CAR). The subject is the students of class XI Textile Craft at SMK Negeri 2 Kayuagung. The data was collected by means of tests, observation, and documentation. Data were analyzed by using a formula percentage of mastery learning. From the results of this study concluded that $\mathrm{h}$ acyl tests in the first cycle in students at SMK Negeri 2 Kayuagung as a whole obtained the average score of students is 70.47 . This value has reached the overall minimum completeness criteria target for students, but at $45.5 \%$ each student's score still needs to be continued in the second cycle to increase student scores through cooperative learning model of the STAD type. In the following cycle, the students' average score was 81.19. From these data, it was obtained one student who had a perfect score of 100 . These results showed that $88.1 \%$ of students who obtained learning completeness in batik crafts were using the STAD cooperative learning model, so there was no need to continue in the next cycle.
\end{abstract}

Keywords: Kriya Batik, Learning, STAD Type, Cooperative Learning Model

\section{INTRODUCTION}

Education is the most important thing that all levels of society must achieve in order for the nation's life to be educated. This means that proper planning is needed to create a learning atmosphere that makes students active in the learning process.

Learning is the training of activities intended to teach skills of students by keeping in mind the powerful storms which perform a part in the story of specific processes that students experience. Education depends a lot on how the learning process can take place in an effective interaction. Learning is the most important activity, that implies that the achievement of improving student learning is heavily dependent on how efficiently the learning process can take place. Education is described as the procedure of interaction between students, educators, and learning resources in an educational environment in article 1 point 20 of Law No.20 of 2003 concerning the National Education System [1].

Supporting success in an education then a learning method plays an important role to determine one's success in delivering learning material educator, with the method can stimulate the creativity of students in learning, especially in the arts and culture that researchers ask.
Learning is a continuous process in order to realize the human creative as possible, in other words that the learning process indeed later did e sain specifically so that learners can be independently, to produce something, to understand the true nature of the learning objectives. The learning objectives themselves are basically the abilities that are expected after gaining learning experiences. Ability in learning includes aspects of attitude (affective), knowledge (cognitive), and skills (psychomotor). Skills that require students to be more likely to be independent and creative are found in many psychomotor skills. Psychomotor skills are performance skills or skills that emphasize the practical ability of students. Psychomotor skills are usually found in practical learning, such as the subject of exploration of cultural arts, for example dance, drama, music, visuals and so on [2].

Fine art is a branch of art that expresses human artistic experience through two-dimensional objects, which are divided into two types, namely pure art and applied art. The fine arts branch consists of, among others, painting, sculpture, painting illustration art, advertisement art, decoration art, and craft.

Today is important for students to understand about understanding craftsmanship, in addition to craft art has its own aesthetic values, craftsmanship is also an art group that can give rise to the creativity of learners to 
bring work that is worth selling in the community. Many craftsmen have proven that with the various works they appear, they can ultimately promote the role of life in society.

Craft art is a branch of pure fine art that is twodimensional (Dwimatara) or three-dimensional (Trimatara), each of which has practical uses. Various kinds of materials that can be used to make handicrafts, such as animal skins, plastics, threads, bamboo, gold, pandanus, and Japanese ribbons. The shape of the works of art craft finished and marketed are bags, floral, batik and carving. In fact, that the art of craft is often intended as work that is produced due to one's skills and skills. However, it raises creative ideas which can then be used as aesthetic selling points, which are very rarely encountered, especially the works of students. The problems vary, from the cognitive shutter of students' knowledge of understanding the art of craft to the main reasons. The survey results were found that usually schools rarely bring up creative ideas in making works of craft art, this is what then raises the main ideas of researchers in addressing this problem.

The basics of making handicrafts usually vary, the old habits of each school usually only bring up ideas of making crafts from clay, such as making ashtrays. It is very rare to find other works that we find in each school of other types of work, even though there are so many models of craft art that students must come up with. This study specializing te $\mathrm{n}$ tang how students $\mathrm{S}$ MK as a place of learning where students' creativity education, particularly craft art in learning the craft of batik. SMK Negeri 2 Kayuagung which is used as a research location is the right choice for researchers to make their students as research subjects, because the art of craft, especially textile crafts, has become one of the departments at SMK Negeri 2 Kayuagung making it easier to carry out research.

Making batik crafts is a representative of students 'creativity in order to develop students' abilities in the psychomotor domain. Making batik crafts needs to be done considering the ease of obtaining materials is the basic consideration of researchers. In order for learning to be more interesting, researchers applied learning methods that were easy to understand by students, STAD of cooperative learning was one of them.

According to Lie in Isjoni [3], the Student Teams Achievement (STAD) learning model, which is a learning technique used by students forming groups of 4-5 students, with each group having distinct academic skills, is a learning technique used by students forming groups of 4-5 students (high, medium and low).

The results of preliminary observations made by researchers at SMK Negeri 2 Kayuagung in the textile craft department obtained data from the homeroom teacher that the results of learning batik crafts on daily tests achieved by students were still low below the KKM standard of 75 which had been determined by the teacher at the school. A total of 28 students from three 6 has received grades below KKM and must follow remedial. This happens because in the Batik Craft learning process it only comes from one information, namely the teacher, so students have not been able to optimize their knowledge to solve problems because students still rely on information only obtained from their teachers, students should be able to get information not only from the teacher, but from other sources, especially among peers in class.

There are two kinds of batik taught in the Textile Craft Department, namely hand-written batik and printed batik. Students are taught to be able to produce batik works that can attract consumers and have high value. In practice, grade XI students are taught to continue practicing chanting on cloth. Students make written and stamped batik individually, starting from making decorations, developing decorative styles, patterns, batik, coloring, and finishing. In the Textile Craft Department of SMK Negeri 2 Kayuagung, students actively carry out learning. Because to train skills, so that quality graduates are created. The knowledge and skills taught are carried out in the textile craft workshops provided by the school.

Class XI batik students in the Textile Craft Department have been trained to compete in the business and industrial worlds, which are supported by sophisticated and comprehensive facilities, competent teaching staff in their fields, comfortable teaching and learning activities, making students more concentrated in their learning. Students' learning outcomes are expected to improve if they use the STAD cooperative learning model.

Observing this, it is time for a renewal to be held with the application of several more varied learning models in order to optimize student potential, so that students avoid feeling bored and create a comfortable and pleasant learning atmosphere which in turn can foster student motivation in learning. As a result, it is anticipated that it will improve student learning outcomes.

Improvement is an effort made by teachers to assist students in improving the learning process so that it is easier to learn. Learning is said to improve when there is a change in the learning process, quality learning outcomes, or the learning experience.

Understanding the two words that comprise it, namely "results" and "learning," helps to explain learning outcomes. The definition of results (product) refers to an acquisition that occurs as a result of the execution of an activity or process that results in a functional change in feedback. Learning is done to seek a change in behavior in individuals who learn [4].

According to Nasution [5] learning outcomes are in the form of a series of words that can be strengthened by many tests. What is necessary is the existence of ideas where the new lesson takes root so that it is integrated with what has been learned. The same opinion was 
expressed by [6] " Learning outcomes are the skills that students acquire as a result of their learning experiences".

The art of craft is a branch of art that has strong roots, namely tradition values that are of high quality or of great value. Because in the past, court craftsmen produced works of art with diligence and high philosophical concepts and provided legitimacy as products of ancient craft art. This concept includes a metaphysical mindset that contains spiritual, religious, and magical values [7].

Apart from that, there is also collective awareness of the natural environment, high solidarity and supported by traditional cultural arrangements which have resulted in craftsmanship of superior quality and reflecting the spirit of the times [8].

In this context, the soul of the age in question is in the form of the entire inner life of humans which consists of feelings, thoughts, and dreams at that time which occur from a certain cultural dialectic that is constantly interacting. Of course, the soul of this age gives bursts of enthusiasm for work to each of the souls of its supporters. Therefore, its superiority is also a work which is then measured from who the supporters and who enjoy it. We know that in certain kingdom times, the differentiation of strata of society, especially the nobility and the common people, was quite strong. Both have different tastes and formally and informally the people's position is often taboo to own or use products that are similar to those in the palace. This then distinguishes, especially in terms of the regional sources of the emergence of craft art, namely works produced from jeron betèng (inside the palace), jaban betèng (outside the palace), and even the coast (coast).

Of course, the mention of a leader is always associated with whatever works are in the palace area. Because, indeed, the handicrafts in the palace have their own legitimacy. That is what makes it so sacred and exalted. So, many people consider it noble because it comes from the palace area. It is different with works made from the jaban keraton area which are considered the work of the common people and are profane, without having a noble or noble meaning [8].

However, the supreme intention at this time was different. Especially with the existence of the Unitary State of the Republic of Indonesia which is no longer a kingdom. Thus, the Indonesian government also protects traditional cultural forms that are deeply rooted and become trade marks for certain regions or certain regions. Especially those that have their own characteristics as part of traditional arts, for example, Jepara carving, Yogya-Solo batik art, Dayak motifs, keris, and so on. A number of works that are also cultural artifacts, of course, have their own value because they are part of the local creativity of the craftsman community.
Batik is derived from the word "tik", which is a fine, soft, and meticulous fabric that contains an element of beauty. Batik can be called a patterned cloth. Etymologically, it means to drip the candle / wax with canting so that it forms a pattern consisting of a drip and a line arrangement. Batik as a noun is the result of drawing patterns on the surface of the cloth with canting and batik wax as a barrier. Etymologically, it means dripping the night with canting so that it forms a pattern consisting of dots and lines [9].

Batik is not only a "beautiful art" in the sense that it is only enjoyed by its aesthetic value, but also as a "useful art", because batik can be used for various purposes. To produce works of art that are beautiful, attractive and not boring in view, in the arrangement of these elements there needs to be rhythm (rhythm), variation, center of interest, and dominance [10].

Batik art is the art of painting etched on cloth for clothing which became one of the cultures of ancient Indonesian kings. Initially, batik was done only limited to the palace and the results for the clothes of the king and his family and followers. Because many of the king's followers lived outside the palace, the batik art was brought by them outside the palace and carried out in their respective places. Batik is a traditional Indonesian dress. Currently, batik has received recognition from UNESCO as a cultural heritage of Indonesia [11].

Many people think that the art of batik has existed in Indonesia about 400 years after Christ. This estimate is based on the existence of batik motifs on the temples. But this has not been proven with certainty. Batik art making has been known in Indonesia for a long time. Batik was brought by the ancestors when moving the population. The Indonesian nation before meeting with Indian culture had known the rules for composing poetry, techniques for making metal industrial batik, planting rice in rice fields by irrigation and had regular governance. Indeed, the arrival of the Indian nation has influenced Indonesian culture so that Indian culture was developed by the Indonesian people in the field of batik.

Type of cooperative learning STAD (Student Teams Achievement Division) is the most fundamental form of cooperative learning. In addition, it can be used to provide students with an understanding of difficult material concepts where the material has been prepared by the teacher through worksheets or other learning tools [12].

Meanwhile, according to Sudjana [13], Student Teams Achievement Division (STAD) is a cooperative learning method or approach that is straightforward and useful for teachers who are just beginning to use a cooperative approach in the classroom. STAD is also an effective cooperative learning method. As previously stated, the STAD type of cooperative learning is made up of five major components: class presentation, group learning, quizzes, growth scores, and group rewards. 
STAD also includes a consistent cycle of teaching activities.

As stated by Listyawati [14], in this model students are grouped into teams with 4 students in each team. The team was formed heterogeneously according to the level of performance, gender, and ethnicity. According to Slavin in Rusman [15], suggests that the learning model STAD (Student Teams Achievement Division) is a variation of cooperative learning, encourage learners to encourage each other and help each other to master the skills taught by the teacher.

Based on some of the expert opinions above, it is concluded that the understanding of the STAD learning model is a learning model that really involves students to learn in heterogeneous groups (level of achievement, gender, culture, and ethnicity) consisting of 4-5 students. Learning activities begin with the delivery of learning objectives, delivery of material, group activities, quizzes, and group awards. The most important feature in the STAD learning model is teamwork.

\section{METHODS}

The research method is the method used by researchers in collecting research data. The research approach used is Action Research (PT), also known as classroom action research, since the classroom is both a small and vital part of the school's learning system.

According to Sudjana [6] classroom action research activities are triggered by practical problems that are directly internalized in the implementation of daily tasks by the teacher as the manager of the classroom learning program. Teachers as teaching staff in a school know practically the various problems faced in their class relating to teaching problems.

The actions to be taken in this cycle are the application of the STAD cooperative learning model. Observation made by observing and then recording the results of the tests that have been carried out in the study. After the actions and observations were carried out, the evaluation of the results of the observations was used to see the level of success of this study, namely whether there was an increase in learning outcomes after the application of the STAD type cooperative learning model

\section{RESULTS AND DISCUSSION}

In cycle I, the application of the STAD type cooperative learning model in the teaching and learning process in the classroom is carried out by the teacher. During the teaching and learning process, students seemed enthusiastic about participating in the learning process, considering that the teacher applied a learning model that invites games that promote student activity, so that students feel less embarrassed and as if they are playing while learning. The application is carried out by the teacher starting from apperception, the STAD type cooperative learning model step, and the final activity. During the teaching and learning process, one of the observers on behalf of Rina Mugiarti, S.Pd., make observations about the course of the teaching and learning process. The results of the observation showed that student activeness at the cycle meeting was included in the active category with an average value of $77.76 \%$, where the oral activeness value of $77.5 \%$ was included in the active criteria, the value of visual activeness was $75 \%$ active, and the value of active work was 80.8 very active.

At the end of the meeting students were given a test to make batik crafts to measure students' understanding and abilities. The overall test results obtained by the mean score of students were 70.47. This value has reached the target of the overall minimum completeness criteria for students, but for each student's value of $55.5 \%$, it still needs to be continued in cycle II to increase student scores through the STAD type cooperative learning model.

In the second cycle as a whole, the average score of students was 81.19. From these data, it was obtained students who had the greatest value, namely 90.This result showed that $88.8 \%$ of students who obtained learning completeness with the STAD cooperative learning model, while the activeness of students in the second cycle were still assessed by the observers of the previous cycle, namely fellow researchers on behalf of Rina Mugiarti, S.Pd., an increase of $5.57 \%$ in the category (quite active) with a value of $80.8 \%$ of active work is in the very active category, an increase of $3.3 \%$ at the second meeting, $80 \%$ of visual activeness is in the very active category, and $89.2 \%$ of active work is included in the very active category, this result increased by $8.4 \%$ from the first cycle.

Students are already active in the teaching and learning process which is marked by activeness in each indicator which has increased from the previous cycle. Students have started to ask questions and actively express opinions to refute statements and answer questions raised by other groups. With this increasing result and having obtained completeness above $85 \%$ indicates that there is no need to continue in the next cycle.

With the results of the study using the STAD cooperative learning model, it was found that the value increased from the pre-cycle, cycle I and cycle II, so it could be concluded that the STAD type cooperative learning model was effectively used in the batik craft learning process at SMK Negeri 2 Kayuagung.

\section{CONCLUSION}

From the results of this study concluded that tests in the first cycle in students at SMK Negeri 2 Kayuagung as a whole obtained the average score of students is 
70.47. This value has reached the overall minimum completeness criteria target for students, but at $45.5 \%$ each student's score still needs to be continued in the second cycle to increase student scores through cooperative learning model of the STAD type. In the following cycle, the students' average score was 81.19. From these data, it was obtained one student who had a perfect score of 100 . These results showed that $88.1 \%$ of students who obtained learning completeness in batik crafts were using the STAD cooperative learning model, so there was no need to continue in the next cycle.

\section{ACKNOWLEDGMENTS}

Our deepest gratitude goes to Teachers in SMK Negeri 2 Kayuagung, Chancellor of Palembang PGRI University, Director of the Postgraduate Program of PGRI Palembang University and the Education Management Study Program of PGRI Palembang University, who have supported us in doing this extraordinary thing. This project is funded independently. We also want to thank our Education Management friends who helped us a lot in a short time frame to complete this project.

\section{REFERENCES}

[1] Undang-Undang Nomor 20 Tahun 2003 tentang Sistem Pendidikan Nasional [Law Number 20 of 2003 concerning the National Education System].

[2] Sagala, S. (2014). Manajemen Berbasis Sekolah dan Masyarakat: Strategi Memenangkan Persaingan Mutu [School and Community Based Management: A Strategy to Win the Competition in Quality]. Jakarta: Nimas Multima.

[3] Isjoni. (2010). Cooverative Learning [Cooverative Learning]. Bandung: Alfabeta.

[4] Purwanto. (2013). Evaluasi Pembelajaran [Learning Evaluation]. Jakarta: Rineka Cipta.

[5] Nasution. (2012). Evaluasi Pendidikan dalam Proses Belajar Mengajar [Evaluation of Education in Teaching and Learning Process]. Bandung: Alfabeta.

[6] Sudjana, N. (2012). Metode Statistika [Statistical Methods]. Bandung: PT. Tarsito Bandung.

[7] Raharjo, T. (2013). Seni Kriya dan Kerajinan [Crafts and Crafts]. Yogyakarta: Kanisius.

[8] Gustami, S. P. (2011). Seni Kriya Indonesia Dilema Pembinaan dan Pengembangannya [Indonesian Craft Art Dilemma Development and Development]. Jurnal Seni, 1/03, BP. ISI. Yogyakarta, p. 107.

[9] Rasjoyo. (2015). Mengenal Batik Tradisional [Getting to know traditional batik]. Jakarta: Azka Press.
[10] Riyanto, D. (2013). Proses Batik [Batik Process]. Surakarta: C.V. Aneka

[11] Prasetyo, A. (2010). Batik. Yogyakarta: Pura Pustaka.

[12] Trianto. (2010). Model Pembelajaran Terpadu [Integrated Learning Model]. Jakarta: PT. Bumi Askara.

[13] Sudjana, N. (2010). Dasar-Dasar Proses Belajar Mengajar [Basics of Teaching and Learning Process]. Bandung: Sinar Baru Algensindo.

[14] Listyawati, S. (2011). Penerapan Model Pembelajaran Student Teams Achivement Division (STAD) untuk meningkatkan hasil belajar dalam menggambar gerak animasi 2 dimensi pada siswa kelas X SMKN 9 Surakarta tahun pelajaran 2009/2010 [Application of Learning Model Student Teams Achivement Division (STAD) to improve learning outcomes in drawing 2dimensional animated motion in class X SMKN 9 Surakarta academic year 2009/2010]. Thesis Universitas Negeri Semarang

[15] Rusman. (2012). Model-Model Pembelajaran [Learning Models]. Jakarta: Raja Grafinah Persada. 